\title{
REVENGE PORN SEBAGAI KEJAHATAN KESUSILAAN KHUSUS: PERSPEKTIF SOBURAL
}

\author{
Hwian Christianto \\ Fakultas Hukum, Universitas Surabaya \\ email: hwall4jc@yahoo.co.id
}

disampaikan 05/9/17 - di-review 12/11/17 - diterima 25/12/17

DOI: $10.25123 /$ vej.2682

\begin{abstract}
Revenge porn, characterized as indecent behavior (morally wrong behavior), is a new phenomenon in Indonesia. The author argues that it would be wrong to perceive this particular act simply as the crime of distributing pornographic material. Moreover, a formal-juridical understanding fails to provide protection and deliver justice to the victim of this particular act (revenge porn). As an alternative and to provide substantial justice, the author suggests to view revenge porn from a criminological outlook and social-cultural-structural approach.
\end{abstract}

Keywords:

revenge porn,; indecency-morally wrong behavior; socio-cultural-structural approach.

\begin{abstract}
Abstrak
Revenge Porn merupakan bentuk kejahatan kesusilaan yang mulai muncul di Indonesia. Tidaklah tepat menyamakan revenge porn begitu saja sebagai tindak pidana penyebarluasan informasi yang melanggar kesusilaan. Lagipula, pendekatan yuridis formal terhadap peristiwa yang dikualifikasi sebagai revenge porn hanya akan memunculkan ketidakadilan substantif bagi korban. Sebagai alternatif dan dalam rangka mewujudkan keadilan substantif, penulis menawarkan pemahaman kriminologis dan sosial-budaya-struktural atas bentuk kejahatan kesusilaan khusus ini.
\end{abstract}

Kata kunci: revenge porn; kejahatan kesusilaan khusus; pendekatan sosial-budaya-struktural.

\section{Pendahuluan}

Revenge porn atau Pornografi sebagai balas dendam merupakan perbuatan pornografi dengan memanfaatkan kepemilikan materi pornografi yang diperoleh secara 'sah' namun disebarluaskan dengan tujuan 'balas dendam' setelah putus hubungan ${ }^{1}$. Tujuan dari pelaku tidak hanya tersebarnya foto pornografi melainkan

1 Shigenori Matsuri, "The Criminalization of Revenge Porn in Japan", Washington International Law Journal Association, Vol. 24 No. 2 2015, hlm. 289 
membalaskan sakit hati yang dialaminya. Penelitian pada perkara pornografi melalui internet menunjukkan bahwa Pornografi sebagai balas dendam merupakan bentuk kejahatan pornografi dengan modus operandi baru. ${ }^{2}$ Beberapa perkara Pornografi sebagai balas dendam telah terjadi dalam berbagai macam bentuk yang berujung pada penyebarluasan materi pornografi. Contoh kasus dikemukakan di bawah ini.

AS awalnya memperoleh 16 foto bugil berupa gambar payudara, belahan payudara dan alat kelamin dari korban sebagai bukti cinta dari korban. Namun saat hubungan cinta mereka berakhir, AS melampiaskan sakit hatinya dengan menyebarluaskan foto tersebut melalui media sosial Facebook dengan akun Kusuma Furry melalui Akun Fitria Saida dan media sosial Whatsapp dengan sarana telpon genggam Iphone 4 miliknya. ${ }^{3}$ Kasus serupa juga terjadi di Mojokerto, ES yang merupakan pasangan nikah siri dari korban pada saat masih berkedudukan sebagai suami istri mendokumentasikan beberapa pose telanjang dari korban. Setelah hubungan tersebut berakhir, ES menyebarluaskan foto tersebut dengan membuat akun Facebook milik ES dan mengunggah foto tersebut. ${ }^{4}$ Perbuatan AS tersebut di atas secara umum dikenal dengan perbuatan pornografi karena menyebarluaskan materi yang melanggar kesusilaan. Hanya saja motif dan latar belakang dilakukannya penyebarluasan dan perolehan foto tidak menjadi pertimbangan kekhususan pornografi. Kasus Pornografi sebagai balas dendam dengan motif berbeda terjadi pada kasus MZM karena MZM bukan kekasih korban. Awalnya korban meminta bantuan MZM untuk menutup akun Facebook "Anis bojone Aldy Selawase" yang memuat foto bugil korban. Akan tetapi MZM justru meminta imbalan dengan melakukan persetubuhan dan meminta foto korban dalam keadaan bugil. MZM sakit hati karena korban telah menjalin

2 Makalah ini merupakan bagian dari Hasil Penelitian Disertasi berjudul "Perumusan Perbuatan Pidana Pornografi melalui Internet berdasarkan Sifat Melawan Hukum Materiil" pada Program Doktor Ilmu Hukum Fakultas Hukum Universitas Gadjah Mada, Yogyakarta

3 Putusan Pengadilan, Putusan Pengadilan Negeri Malang No.645/Pid.Sus/2015/PN.Mlg, tanggal 17 Februari 2016

${ }^{4}$ Putusan Pengadilan, Putusan Pengadilan Negeri Mojokerto No. 425/Pid.Sus/2015/PN Mjk tanggal 24 November 2015 
hubungan asmara dengan laki-laki lain sehingga ia mengunggah foto tersebut ke akun media sosial miliknya Facebook "M.Zakka@yahoo.com" dan akun media sosial milik korban. ${ }^{5}$ Dalam kasus tersebut penegak hukum hanya mengenakan MZM dengan Pasal 29 jo Pasal 4 ayat (1) UU No. 44 tahun 2008 tentang Pornografi (UU Pornografi) sebagai perbuatan memproduksi, membuat dan menyebarluaskan pornografi.

Penggunaan ketentuan hukum pasal 29 jo Pasal 4 ayat (1) UU Pornografi hanya menekankan perbuatan pornografi secara umum. Padahal perbuatan ini memiliki karakteristik berbeda dengan penyebarluasan pornografi pada umumnya, yaitu dari sisi perolehan atau kepemilikan materi pornografi dan tujuan menyebarluaskan materi pornografi. Penegak hukum pun terpaku pada pendekatan legalistik-positivistik ${ }^{6}$ yang hanya mengutamakan pemenuhan unsur perbuatan pidana dalam Pasal 29 jo Pasal 4 ayat (1) UU Pornografi. Akibatnya pemeriksaan perkara semakin jauh dari pemenuhan keadilan yang diharapkan masyarakat. Hakim pun hanya menilai perkara MZM sebagai perbuatan yang terbukti melanggar rumusan Pasal 29 jo pasal 37 UU Pornografi ${ }^{7}$ tanpa melihat motif dilakukannya penyebaran pornografi dan nilai-nilai hukum yang hidup secara progresif ${ }^{8}$ di masyarakat Banyuwangi. Pendekatan tersebut perlu dipertajam dengan pemahaman kriminologis yang melihat Pornografi sebagai balas dendam dari sisi sosial, budaya dan faktor struktural dilakukannya kejahatan. Pendekatan Sobural mengkaji perbuatan dari sisi nilai masyarakat yang dilanggar dari perbuatan pornografi sebagai balas dendam, nilai budaya yang tidak dipenuhi oleh pelaku dengan melakukan penyebaran pornografi serta pemahaman struktural yang menyebabkan pelaku melakukan pornografi. Berdasarkan latar belakang tersebut dapat diajukan beberapa rumusan masalah

5 Putusan Pengadilan, Putusan Pengadilan Negeri Banyuwangi No. 726/Pid.Sus/2015/PN Bwi tanggal 3 Maret 2016

${ }^{6}$ A.M. Mujahidin, Hukum Progresif: Jalan Keluar dari Keterpurukan Hukum di Indonesia XXII 257 Varia Peradilan, 2007, hlm 52.

7 Supra no 5

${ }^{8}$ Hwian Christianto, Penafsiran Hukum Progresif dalam Perkara Pidana 233 Jurnal Mimbar Hukum, 2011, hlm 482. 
untuk mempertajam pendalaman arti penting pendekatan Sobural terhadap pornografi sebagai balas dendam. Yaitu arti penting penggunaan pendekatan Sobural dikaitkan dengan pornografi sebagai balas dendam dan pornografi sebagai balas dendam sebagai kejahatan kesusilaan khusus berdasarkan pendekatan Sobural.

Berkaitan dengan pemahaman terhadap pornografi sebagai balas dendam sebagai kejahatan kesusilaan khusus berdasarkan pendekatan Sobural maka dipilih metode penelitian yuridis empiris. Pemilihan data primer ditekankan pada penggunaan dokumen hukum berupa peraturan perundang-undangan terkait pornografi sebagai balas dendam dikaitkan dengan teori hukum pidana yang terkait sedangkan data sekunder menggunakan putusan hukum pengadilan negeri yang memeriksa perkara pornografi sebagai balas dendam. Data primer akan digunakan sebagai acuan dalam memahami maksud dan tujuan pembentukan norma hukum yang melarang pornografi dikaitkan dengan pemahaman penegak hukum dalam pertimbangan putusan perkara pornografi sebagai balas dendam. Pemahaman secara mendalam terhadap pertimbangan hakim atas perkara pornografi sebagai balas dendam dilengkapi dengan dokumen rekapitulasi kuisioner dan wawancara hakim. Hasil perbandingan dari norma hukum dengan pertimbangan hakim ditarik sebuah kesimpulan akan pentingnya pendekatan Sobural dalam menilai pornografi sebagai balas dendam.

\section{Pembahasan}

\section{Revenge Porn sebagai Perbuatan Pidana}

Perbuatan revenge porn atau pornografi sebagai balas dendam sering disebut dengan istilah lain 'Non consensual pornography' atau 'involuntary pornography'9 karena penyebarluasan materi asusila tidak mendapatkan persetujuan dari korbannya. Citron \& Franks menegaskan pengertian revenge

\footnotetext{
9 Danielle Keats Citron \& Mary Anne Franks, “Criminalizing Revenge Porn”, https://law.yale.edu/system/files/area/center/isp/documents/danielle_citron_-_criminalizing_ reve-nge_porn_-_fesc.pdf, (terakhir diakses) 12 September 2017, hlm. 102
} 
porn sebagai "the distribution of sexually graphic images of individuals without their consent."10 atau pendapat Kirchengast sebagai "the sharing of intimate images without the consent of the person depicted,..."11. Definisi berbeda dikemukakan Matsui yang mendeskripsikannya sebagai "the practice of posting and distributing sexually explicit images of an ex-partner on the Internet after a breakup."12 Serupa namun tak sama kedua definisi tersebut memiliki penekanan berbeda. Definisi pertama lebih menekankan pentingnya 'their consent to publish sexually graphic' atau persetujuan untuk menyebarluaskan materi pornografi sehingga apabila kedua belah pihak (pembuat dan model) tidak setuju, hal ini dianggap merupakan kejahatan. Pemahaman pertama ini jika dikaitkan dengan hukum pidana Indonesia, secara khusus pornografi tidak dapat diterapkan. Penyebarluasan materi pornograi walaupun atas persetujuan dari kedua belah pihak tetap merupakan perbuatan pidana. UU Pornografi hanya memberikan pembuatan pornografi untuk kepentingan sendiri (Penjelasan Pasal 4 ayat (1) UU Pornografi tidak termasuk di dalamnya untuk disebarluaskan. Lebih lanjut pada definisi kedua, perbuatan pornografi sebagai balas dendam menjadi dilarang karena menyebarluaskan materi pornografi dari mantan kekasih (ex-partner) sehingga penekanannya pada substansi pornografi yang melanggar ketentuan hukum. Definisi kedua ini dapat diterima dalam UU Pornografi karena pornografi sebagai balas dendam merupakan salah satu bentuk dari pornografi hanya tidak mencatat ciri khas perbuatannya.

Perbedaan definisi pornografi sebagai balas dendam dilatar belakangi oleh perbedaan penilaian pencelaan atas perbuatan pornografi sebagai balas dendam. Dengan melihat definisi pornografi sebagai balas dendam (revenge pornography) sebelumnya dapat dipahami bahwa penilaian revenge porn diletakkan pada ada atau tidaknya kerugian yang dialami seseorang (an egregious privacy violation ${ }^{13}$ )

\footnotetext{
$10 \mathrm{Id}$.

11 Tyrone Kirchengast, "The Limits of Criminal Law and Justice: 'revenge porn' Criminalisation, Hybrid Responses and The Ideal Victim", UniSA Student Law Review, Vol. 2, hlm. 96

12 Supra no 1.

13 Supra no 9.
} 
sebagai akibat tidak diberikannya persetujuan untuk menyebarluaskan materi pornografi. Terkait dengan hal tersebut, larangan pornografi Indonesia tidak memiliki kesamaan. Pasal 1 angka 1 UU Pornografi meletakkan norma kesusilaan sebagai dasar penilaian utama pornografi. Ada atau tidaknya persetujuan tidak menjadi ukuran dalam pencelaan pornografi (revenge porn). Perihal substansi bahwa pornografi menjadi dilarang karena melanggar hukum menurut hukum pidana Indonesia tidak sepenuhnya dapat diterima. Pembuatan suatu karya merupakan hak dari setiap orang hanya saja pembuatan materi yang memiliki muatan pornografi merupakan perbuatan yang melanggar kesusilaan (Pasal 1320 KUH perdata dan Pasal 50 UU Hak Cipta 2014) sehingga tidak pernah mendapatkan pengakuan atau perlindungan. Pemahaman ini ternyata tidak sesuai dengan Penjelasan Pasal 4 ayat (1) UU Pornografi bahwa larangan pembuatan pornografi dikecualikan untuk kepentingan sendiri. Pengaturan tersebut merupakan bentuk inkonsistensi dari larangan pornografi yang membuka ruang bagi pembuatan pornografi baru atas nama kepentingan sendiri namun pada akhirnya disebarluaskan atau tersebarluas di masyarakat.

Konstruksi perbuatan pornografi sebagai balas dendam jika dikaji menurut UU Pornografi memang tidak diatur secara khusus. Sebagai lex specialist dari KUHP, UU Pornografi melarang 10 (sepuluh) bentuk perbuatan antara lain (1) memproduksi, membuat, memperbanyak, menggandakan, menyebarluaskan, menyiarkan, mengimpor, mengekspor, menawarkan, memperjualbelikan, menyewakan atau menyediakan pornografi, (2) Menyediakan jasa pornografi, (3) meminjamkan atau mengunduh ponorgrafi (4) Memperdengarkan, mempertontonkan, memanfaatkan, memiliki atau menyimpan produk pornografi, (5) Mendanai atau memfasilitasi perbuatan pada Pasal 4 (6) menjadi obyek/model pornografi atas persetujuan diri sendiri, (7) Menjadikan orang lain sebagai obyek/model pornografi, (8) Mempertontonkan diri atau orang lain di muka umum yang bermuatan pornografi, (9) Melibatkan anak dalam kegiatan dan/atau sebagai obyek pornografi, dan (10) Mengajak, membujuk, memanfaatkan, membiarkan, menyalahgunakan kekuasaan atau memaksa anak dalam 
menggunakan produk/jasa pornografi. Dari kesepuluh bentuk perbuatan yang dilarang tersebut, belum ada satu ketentuan hukum pun yang mengatur perihal perbuatan pornografi sebagai balas dendam. Padahal karakteristik pornografi sebagai balas dendam berbeda dari sekedar pembuatan atau penyebarluasan pornografi. Berdasarkan kasus AS, pembuatan pornografi justru disetujui oleh kedua belah pihak namun tidak dalam hal penyebarluasannya. Begitu pula dalam Kasus MZM, perolehan materi pornografi justru diberikan oleh korban walaupun dengan imbalan tertentu. Akhirnya, MZM sakit hati dan menyebarluaskannya di akun media sosial facebook.

Aspek penting pengaturan revenge porn juga dapat dilihat dari dampak negatif yang dirasakan baik oleh korban maupun masyarakat. Citron \& Franks menunjukkan hasil penelitian dampak pornografi sebagai balas dendam pada the risk of offline stalking and physical attack ${ }^{14}$ to the victim. Korban akan mengalami tekanan psikologis yang berat akibat tersebarnya foto asusila atau video asusila karena terus menjadi bahan perbincangan masyarakat setiap waktu. Bagi masyarakat, keberadaan tersebarluasnya foto asusila atau video asusila menimbulkan keresahan akibat dilanggarnya norma kesusilaan masyarakat. Belum lagi foto atau video tersebut sulit dihapus karena dilipatgandakan secara terus menerus oleh pengguna internet lainnya.

\section{Norma Kesusilaan: Ukuran Pencelaan Revenge porn}

Sejak awal UU Pornografi telah menegaskan bahwa ukuran penialaian dari pornografi diletakkan pada norma kesusilaan. Ketentuan hukum Pasal 1 angka 1 UU Pornografi menegaskan bahwa norma kesusilaan menjadi ukuran dalam menilai semua informasi yang disebarluaskan dalam berbagai bentuk media. Penggunaan norma kesusilaan dalam menentukan suatu perbuatan sebagai perbuatan pidana juga telah dikenal jauh sebelum diberlakukannya UU Pornografi, yaitu Pasal 282 ayat (1) KUHP. Istilah yang digunakan dalam Pasal 282 ayat (1)

14 Supra no 11., hlm. 105 
KUHP atau Pasal 240 Sr. adalah aantotelijk vor de eerbaarheid yang dipahami sebagai "melanggar kesusilaan"15 atau "melanggar kesopanan".16 Pemahaman ahli hukum pun terbagi menjadi 2 (dua) kelompok. Pertama kelompok yang memahami norma kesusilaan sebagai aturan yang berasal dari hati nurani kemanusiaan dan kedua, kelompok yang memahami norma kesusilaan sebagai aturan terkait dengan hal-hal seksual. Kanter dan Sianturi17 menjelaskan norma kesusilaan sebagai ketentuan bertingkah laku di masyarakat yang didasarkan pada hati nurani untuk menentukan tingkah laku yang baik dan tingkah laku yang jahat. Pemahaman Kanter dan Sianturi jika diamati lebih menekankan norma kesusilaan sebagai ukuran penilaian yang hakiki dalam diri manusia yang ada secara alamiah. Artinya, ukuran ini merupakan tanda kemanusiaan yang menunjukkan dirinya memiliki harkat dan martabat sebagai makhluk ciptaan Tuhan yang mulia. Kesusilaan tidak hanya menyangkut tentang hubungan diri dengan orang lain melainkan semua relasi yang ada dalam kehidupan manusia. Pemahaman berbeda dikemukakan oleh kelompok kedua yang diwakili oleh Soesilo dan Indrijanto Seno Adji yang menyatakan norma kesusilaan berhubungan dengan "perasaan malu yang berhubungan dengan nafsu kelamin"18 atau "soal cabul/obscenity"19. Pandangan yang terakhir ini rupanya lebih dipahami oleh penegak hukum dalam menangani kejahatan kesusilaan. ${ }^{20}$

\footnotetext{
${ }^{15}$ Moeljatno, KUHP: Kitab Undang-Undang Hukum Pidana, Bumi Aksara, Jakarta, 2011, hlm 102103

${ }^{16}$ R. Soesilo, Kitab Undang-Undang Hukum Pidana (KUHP) serta Komentar-Komentarnya Lengkap Pasal Demi Pasal, Politeia, Bogor, 1974, hlm. 177-178

${ }^{17}$ E.Y. Kanter dan S.R. Sianturi, Asas-asas Hukum Pidana di Indonesia dan Penerapannya, Storia Grafika, Jakarta, 2012, hlm 26-27

${ }^{18}$ Supra no 16.

${ }^{19}$ Indriyanto Seno Adji, Prospek Hukum Pidana Indonesia pada Masyarakat yang Mengalami Perubahan, 63 Jurnal Keadilan. 6, 16 (2003).

${ }^{20}$ Toetik Rahayuningsih, Kejahatan Kesusilaan dan Upaya Penanggulangannya: Studi pada Tingkat Penyidikan, Penuntutan dan Pemeriksaan di Pengadilan Negeri Surabaya, Fakultas Hukum Universitas Airlangga, 22 April 2014, http://adln.lib.unair.ac.id/go.php?id=gdlhub-gdl-res-2014rahayuning-34480\&q=kesusilaan, (terakhir diakses 12 Mei, 2017).
} 


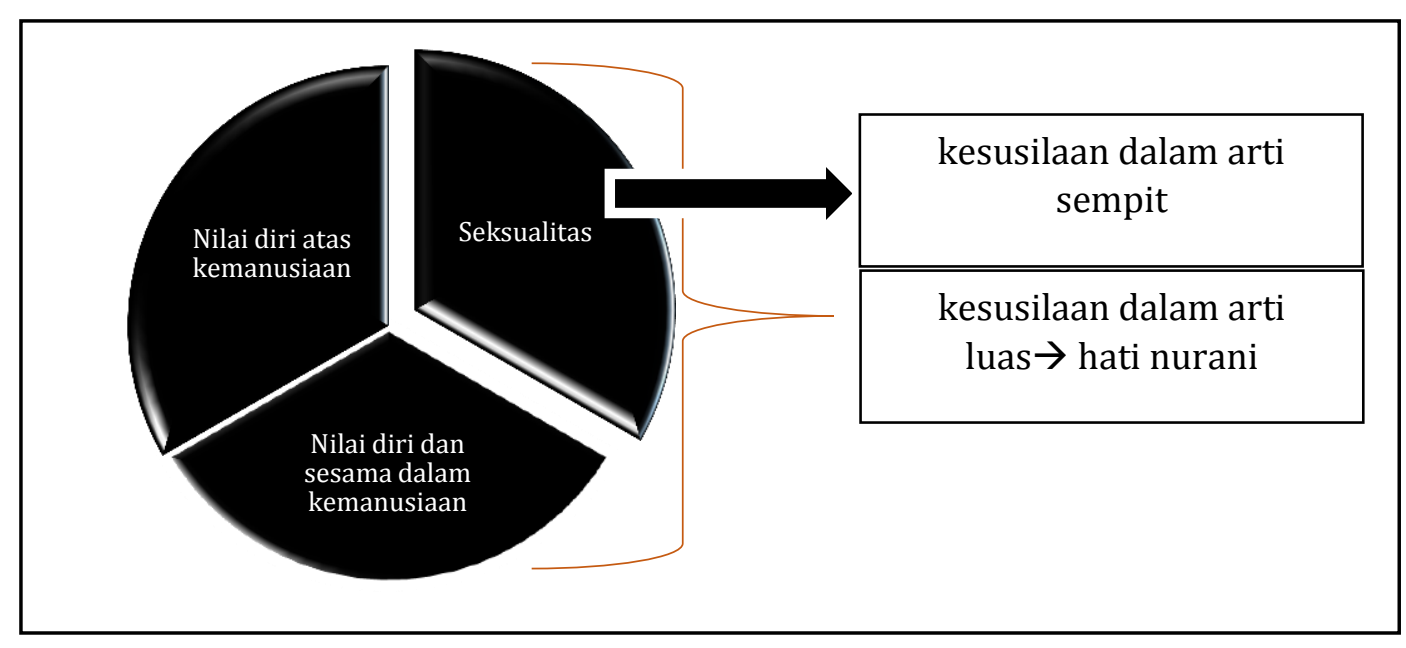

Bagan 1: Pemahaman Ruang Lingkup Kesusilaan

Terkait dengan perbedaan pemahaman tersebut, penggunaan norma kesusilaan jika mempertimbangkan posisi Pasal 282 ayat (1) KUHP berada pada lingkup kejahatan kesusilaan yang mengatur larangan perbuatan gendak (overspel), percabulan, perkosaan, persetubuhan dengan wanita di bawah umur, penghubungan pencabulan, penyebarluasan materi yang melanggar kesusilaan, memberikan informasi tentang pencegahan kehamilan, dan persetubuhan dengan anak yang memiliki jenis kelamin yang sama. Hal tersebut menunjukkan bahwa norma kesusilaan yang dimaksudkan adalah aturan yang berasal dari hati nurani kemanusiaan. Hal tersebut pada dasanya merupakan pemahaman hukum sebagai nilai-nilai kesusilaan yang minimal (das recht ist das ethische minimum) ${ }^{21}$. Perbuatan-perbuatan yang diatur dalam Bab XIV Buku II KUHP tidak hanya menekankan perihal seksual saja melainkan perbuatan yang dinilai tidak layak dilakukan karena merendahkan kemanusiaan orang lain.

Penggunaan norma kesusilaan sebagai ukuran penilaian bagi revenge porn sebenarnya dapat dilakukan mengingat larangan pornografi didasarkan pada noma kesusilaan. Revenge porn dapat dilakukan oleh pelaku karena ia memiliki materi yang melanggar kesusilaan dan menyebarluaskannya atas dasar benci atau

${ }^{21}$ Ismansyah \& Ermawati B, Permasalahan Delik Zina Yang Terdapat dalam Kitab Undang-Undang Hukum Pidana (KUHP) IX 1 Jurnal DELICTI 27 (2012). 
dendam. Perolehan materi yang melanggar kesusilaan pada dasarnya tidak melanggar undang-undang. Hal tersebut didasarkan pada pengaturan Penjelasan Pasal 4 ayat (1) UU Pornografi bahwa pornografi untuk kepentingan sendiri dikecualikan dalam larangan Pasal 4 ayat (1) UU Pornografi. Walaupun demikian perolehan materi tersebut jika ditinjau dari norma kesusilaan tidak dapat dibenarkan. Ketelanjangan, hubungan seksual, alat kelamin dan perbuatan seksual lainnya pada hakikatnya merupakan bagian dari natur organ reproduksi dan kebutuhan reproduksi yang dirancang secara mulia oleh Tuhan Yang Maha Esa. Kondisi tersebut sekalipun mulia tidak boleh diperlakukan dengan sembarangan atau tidak pada peruntukkannya. Bahwa perbuatan tersebut berkaitan dengan hal reproduksi atau seks maka harus dilakukan dengan rasa hormat dan tanggung jawab terhadap kemanusiaan. Segala upaya yang bersifat merendahkan atau membuat kemanusiaan turun harkat dan martabatnya harus dihindari.

Pembuatan materi pornografi sebagaimana terjadi pada kasus AS dan kasus MZM menunjukkan adanya persetujuan dari kedua belah pihak untuk mendokumentasikan kondisi atau perbuatan mereka yang menunjukkan ketelanjangan, alat kelamin atau hubungan seks. Persetujuan yang diberikan oleh kedua belah pihak jika dilihat dari sisi hak asasi manusia memang termasuk dalam hak untuk bebas menentukan apa yang terbaik bagi dirinya (Pasal 28E ayat (2) UUD 1945), hak untuk berpendapat/berekspresi (Pasal 28I UUD 1945), hak untuk memiliki dan menyimpan informasi (Pasal 28F UUD 1945) dan hak atas perlindungan diri pribadi (privasi) (Pasal 28G UUD 1945). Keempat hak konstitusional tersebut memang dimiliki dan diakui keberadaannya oleh UUD 1945 hanya saja di sisi lain perlu mempertimbangkan hak dan kebebasan orang lain dalam tertib kehidupan bermasyarakat, berbangsa dan bernegara (Pasal 28J ayat (1) UUD 1945). Artinya, pelaksanaan hak tersebut harus dipertimbangkan dengan seksama akan memiliki manfaat positif bagi orang lain, masyarakat dan bangsa atau sebaliknya. Tinjauan norma kesusilaan terhadap pornografi sebagai balas dendam dapat dilihat dari 2 (dua) sisi yaitu sisi substansi materi pornografi dan motivasi penyebarluasan materi pornografi. Jika dilihat dari substansi materi 
pornografi yang menunjukkan ketelanjangan, alat kelamin dan persetubuhan/hubungan seks maka informasi tersebut ditujukan untuk 'merayakan kepuasan seksual'. Atau dengan kata lain, substansi pornografi menunjukkan pasangan sebagai obyek seksual semata. Hal tersebut sama artinya dengan merendahkan harkat dan martabat kemanusiaan yang melanggar norma kesusilaan. Penyebarluasan materi pornografi jika dikaji lebih jauh sebenarnya merupakan bentuk pengingkaran atau melanggar persetujuan dari janji pembuatan materi asusila. Awalnya, pelaku dan/atau korban menyetujui pembuatan materi asusila diperuntukkan untuk kepentingan pribadi. Perbuatan menyebarluaskan materi asusila tersebut jelas menciderai harkat kemanusiaan yang harus menjunjung tinggi janji dengan sesama. Penyebarluasan materi pornografi juga menunjukkan pelanggaran terhadap norma kesusilaan dari motivasi pelaku yang bertujuan untuk membalaskan sakit hati atau balas dendam dan menginformasikan kepada masyarakat luas akan perbuatan tidak senonoh dari korban. Kedua motivasi tersebut jelas menunjukkan upaya merendahkan derajat kemanusiaan sebagai perbuatan main hakim sendiri dan membuat malu korban. Pertimbangan tersebut justru tidak muncul dalam pertimbangan putusan hakim atas perkara SA maupun MZM. Perbuatan SA dan MZM hanya dinilai sebagai perbuatan pornografi pada umumnya karena memenuhi Pasal 29 jo Pasal 4 UU Pornografi. ${ }^{22}$

\section{Sobural sebagai Pendekatan Kriminologi ala Indonesia}

Pendekatan kriminologi memiliki hubungan yang sangat dekat dengan hukum pidana. Kajian hukum pidana berfokus pada penentuan perbuatan pidana dan pertanggungjawaban apabila terdapat pelanggaran terhadap ketentuan hukum pidana. Kriminologi memberikan bantuan dalam memahami sebab musabab atau kausa suatu kejahatan. Sumbangsih kriminologi bagi hukum pidana sangat besar dalam upaya pemahaman suatu perbuatan untuk dapat dinilai atau disebut sebagai kejahatan yang jika kemudian ditetapkan oleh undang-undang

22 Supra no 5 
menjadi perbuatan yang dilarang. Berbagai pendekatan kriminologi telah dikenalkan sebagai upaya memahami kejahatan hanya saja masih sedikit pendekatan kriminologi yang didasarkan atas situasi dan kondisi masyarakat Indonesia.

Sobural, akronim dari nilai Sosial, nilai Budaya dan faktor Struktural merupakan pendekatan kriminologi yang digagas oleh ahli hukum Indonesia, Jacobus Elfinus Sahetapy. Di tengah berbagai macam aliran kriminologi dan teori kriminologi yang berkembang di Eropa dan Amerika, Sahetapy memiliki gagasan untuk membentuk suatu kerangka kriminologis dalam memahami kejahatan yang terjadi di Indonesia. Hal tersebut begitu penting jika mengingat tipe pluralisme masyarakat Indonesia dan perkembangan masyarakat yang begitu cepat sangat berbeda jika dibandingkan dengan masyarakat Eropa dan Amerika. Pendekatan Sobural memiliki 3 (tiga) acuan dalam memahami kejahatan, yaitu nilai apakah yang dianut oleh suatu masyarakat, nilai budaya apakah yang terbentuk selama waktu tertentu dan adakah pengaruh faktor struktural dalam penilaian suatu perbuatan. Jika diperhatikan dengan seksama, Sobural tidak pernah meninggalkan pemahaman konsteks kehidupan masyarakat tempat pelaku melakukan perbuatan yang dilarang. Hal inilah yang menjadi tanda yang tidak dapat dielakkan bahwa pemikiran Sobural lahir pada masa pemikiran Kriminologi Modern. Salah satu ciri khas pemikiran Kriminologi Modern adalah berupaya menempatkan pengamat kriminologi sebagai subyek bersamaan dengan masyarakat yang diteliti. Masyarakat menyediakan konteks utuh untuk mengkonstruksikan sebuah perbuatan sebagai kejahatan mengingat hakikat masyarakat merupakan sistem nilai. Hal tersebut jauh berbeda dengan pemikiran Kriminologi Klasik yang menempatkan ilmu pengetahuan sebagai sarana utama memahami kejahatan. Konsekuensi dari kedua pemikiran Kriminologi tersebut juga berdampak pada peran hukum terhadap kejahatan. Kriminologi klasik pada akhirnya menempatkan hukum sebagai alat untuk mengantisipasi kejahatan yang terjadi bahkan menjadi obat utama (primum remidium). Berbeda dengan 
pemikiran modern yang menempatkan hukum sebagai bagian dari proses sosial yang dibentuk oleh masyarakat di suatu waktu tertentu.

Pemahaman terhadap pendekatan Sobural sebagai pemikiran Kriminologi moderen tidak berarti pendekatan Sobural memiliki kesamaan secara keseluruhan dengan teori kriminologi yang berkembang pada masa itu. Pemikiran Sobural diawali dengan sebuauh preposisi "manusia tidak hidup dalam kekosongan. Ia akan bergerak dalam suatu skala Sobural."23 Maksud dari preposisi ini menunjukkan bahwa dalam sebuah masyarakat terdapat sebuah kesepakatan nilai apa yang akan dijunjung tinggi demi menjaga kehidupan bersama. Tidak ada satu masyarakat pun yang tidak memiliki kesepakatan nilai apa yang akan dijunjung, karena jika demikian adanya, maka masyarakat itu tidak ada. Individu sebagai anggota masyarakat bahkan aktor dalam kehidupan masyarakat pun dengan penuh pengakuan dan kesadaran menerima kesepakatan nilai tersebut sebagai suatu ukuran yang layak dalam menilai perbuatan. Berdasarkan pemahaman inilah apabila seseorang melakukan perbuatan yang tidak sesuai dengan skala nilai yang diemban oleh masyarakat maka ia sedang melakkukan suatu penyimpangan dari nilai sehingga harus dikenakan sanksi. Proses pengakuan akan nilai ini dalam sistem ketatanegaraan dilakukan melalui tahap legislasi dalam peraturan perundang-undangan pidana yang di dalamnya disertai ancaman sanksi bagi pelanggaran yang terjadi.

Individu yang melakukan penyimpangan menurut teori Sobural perlu dilihat sebab musababnya dari kondisi masyarakat tempat dimana pelaku berada. Seseorang melakukan kejahatan pada dasarnya menunjukkan ketidakmampuan dirinya dalam melakukan penyesuaian dengan nilai yang dianut oleh suatu masyarakat. Kegagalan tersebut dapat berupa ketidakpahaman arti penting nilai yang diemban bahkan penolakan nilai secara mentah-mentah. Pemahaman akan munculnya kejahatan sebagai tanda kegagalan proses penyesuaian indvidu terhadap tatanan nilai yang dianut masyarakat memiliki kesamaan dengan pemahaman teori interaksionis yang dikembangkan oleh Émile Durkheim. Adler

${ }^{23}$ J.E. Sahetapy, Teori Kriminologi: Suatu Pengantar, Citra Aditya Bakti, Bandung, 1992, hlm 66 
menjelaskan pandangan Durkheim menjelaskan terjadinya penyimpangan individu sebagai berikut : "the explanation of human conduct and indeed human misconduct, lies not in the group and the social organization. It is in this context that he introduced term 'anomie', the breakdown of social order as a result of the loss of standards and values."24 Perbuatan seseorang pada dasarnya menunjukkan penghayatan akan nilai yang dianut oleh masyarakat tempat dimana ia hidup. Ketika pelaku gagal menyesuaikan diri dengan masyarakat, Sahetapy mengutip pendapat Cooley ${ }^{25}$ mengatakan pelaku sedang mengalami kegagalan dalam berinteraksi baik dari sisi nilai diri (material self) maupun nilai sosial (social self). Jika Cooley memahami penyimpangan sebagai kegagalan penyesuaian dari pelaku, Sahetapy lebih fokus pada pemahaman situasi dan kondisi masyarakat secara kontekstual di Indonesia.

Kontekstual masyarakat Indonesia diusung sebagai ciri khas pendekatan Sobural. J.E. Sahetapy ${ }^{26}$ menjelaskan bahwa pemahaman terhadap kejahatan di dalam masyarakat Indonesia sangatlah unik karena melibatkan 3 (tiga) hal utama, nilai sosial, aspek budaya dan faktor struktural masyarakat. Pandangan ini berbeda sekali dengan pemahaman teori interaksionis yang hanya melihat nilai masyarakat yang diakui tetapi tidak menghadirkan aspek budaya dan faktor struktural yang hanya ada di masyarakat Indonesia. Tiga proposisi utama yang harus dipahami yaitu Pertama, skala nilai sosial pada masyarakat dibentuk oleh nilai agama, budaya dan sosial, Kedua, kepatuhan dalam korelasi kontekstualisasi realitas sosial dan Ketiga, keberadaan manusia sebagai makhluk ciptaan Tuhan. ${ }^{27}$ Ketiga hal inilah yang menjadi 'pisau bedah' dalam memahami kejahatan dalam konteks masyarakat Indonesia.

${ }^{24}$ Freda Adler, Gerhard O.W. Mueller \& William S. Laufer, Criminology and the Criminal Justice System 116 (Mcgraw Hill, New York, 2007, hlm 116.

25 J.E. Sahetapy, Elfina Sahetapy, ed., Pisau Analisis Kriminologi 24, Citra Aditya Bakti, Bandung, 2005, hlm 24.

26 Id., 20-21

27 J.E. Sahetapy, Pisau Analisa Kriminologi: Pidato Pengukuhan Guru Besar Fakultas Hukum Universitas Airlangga 82-84 
Proposisi pertama menegaskan kesadaran akan realitas masyarakat pluralisme yang memiliki nilai sosial bermacam-macam. Pemahaman nilai sosial tidak diartikan sebagai pemahaman prinsip kehidupan yang berbeda antara satu masyarakat dengan masyarakat lainnya. Nilai sosial merupakan nilai yang dihayati dari nilai kemanusiaan yang adil dan beradab sebagai ciri khas masyarakat Indonesia. Pancasila tetap menjadi bingkai dalam menghayati nilai sosial yang dimaksudkan. Pancasila tetap menjadi sumber acuan dan cara pandang hidup bangsa Indonesia dalam bermasyarakat. Febrianty menegaskan bahwa "Pancasila as an ideology can make us unity politically represent and refine any interest."28 Nilai sosial yang terbentuk di masyarakat dapat berbeda satu sama lain namun memiliki prinsip yang sama memanusiakan manusia. Terkait dengan pemahaman nilai sosial, Sobural beririsan pemahaman dengan teori Merton yang tidak melupakan masyarakat bagi terciptanya kejahatan. Merton menjelaskan terjadinya kejahatan sebagai berikut ${ }^{29}$ :

"it is only when a system of cultural values extols, virtually above all else, certain common symbols of success for the population at large while its social structure rigorously restricts or completely eliminates access to approved modes of acquiring these symbols for a considerable part of the same population, that antisocial behavior ensues on a considerable scale."

Oleh karena itu pemahaman akan kejahatan tidak boleh meninggalkan pemahaman terhadap penilaian sosial terhadap perbuatan yang disebut sebagai kejahatan itu. Artinya, pendekatan nilai sosial memberikan kesempatan bagi pemahaman kriminologi untuk mencari cara pandang faktual dengan menggali nilai hukum yang hidup di masyarakat.

Proposisi kedua, kontekstualisasi realitas sosial merupakan kunci dari pemahaman aspek budaya yang ditekankan Sobural. Pemahaman terhadap kejahatan tidak boleh melupakan pemahaman kondisi realitas masyarakat yang menganut suatu sistem kebiasaan atau tatanan perilaku tertentu. Kepatuhan

\footnotetext{
${ }^{28}$ Gabriella Febrianty, Philosophy, Pancasila and Modern Technology 292 Jurnal Yuridika, 2014, hlm 125.

${ }^{29}$ Supra no 23, hlm. 117.
} 
anggota masyarakat menjadi kebiasaan hidup yang melembaga dalam tatanan kebiasaan yang dinilai baik. Kaitannya dengan teori Kriminologi modern, pemahaman budaya yang berlaku di suatu tempat memiliki fungsi yang sama dengan teori Kontrol sosial Hirschi. J.E. Sahetapy menjelaskan bahwa pemahaman atas aturan hukum sebagaimana diungkapkan oleh Hirschi menempatkan manusia sebagai makhluk amoral yang harus patuh terhadap aturan hukum dan norma masyarakat. ${ }^{30}$ Peran hukum yang berisikan norma disini menurut Widowati ${ }^{31}$ memiliki keterkaitan dengan upaya mempertahankan kehidupan bermasyarakat sehingga bersifat mewajibkan. Lebih lanjut Hirschi menyebutkan 4 (empat) hal yang dapat mengikat kepatuhan seseorang untuk tidak berbuat kejahatan, yaitu (1) attachment atau integrasi nilai yang baik sejak awal, (2) Commitement, ketertarikan pada subsitem yang berlaku sejak lama, (3) Involvement, keterlibatan anggota pada subsistem yang berlaku misalnya pada tiap momen budaya, dan (4) belief, percaya dan menerapkan nilai moral pada pergaulan hidup sehari-hari. ${ }^{32}$ Kondisi budaya disini merupakan hal yang sangat menentukan dalam membentuk pemahaman seseorang akan suatu perbuatan bahkan mempengaruhi dirinya untuk melakukan atau tidak melakukan sesuatu dalam kehidupan sehari-hari. Masyarakat dalam pendekatan budaya juga terus mengupayakan penghayatan nilai budaya dalam diri anggota masyarakat dalam bentuk pendidikan budaya dan sanksi bagi pelanggaran yang ada.

Proposisi ketiga dari pendekatan Sobural menjadi tanda beda dari pendekatan kriminologi lainnya. Ketika teori kriminologi modern berhenti pada pemahaman kemasyarakatan sebagai titik tolak dan sumber penilaian perbuatan, Sobural justru menghunjam pada jantung masyarakat Indonesia. Keterikatan masyarakat Indonesia dan sistim nilai yang dihayati dalam kehidupan bersama tidak lahir dari kesepakatan antar anggota masyarakat maupun penetapan dari pihak yang berkuasa. Penghayatan akan nilai masyarakat Indonesia bermuara

\footnotetext{
30 J.E. Sahetapy, supra no. 12, hlm. 43

${ }^{31}$ Christina Widowati, Hukum sebagai Norma Sosial memiliki Sifat Mewajbkan, 14 Jurnal Hukum ADIL. 150-167 (2013).

32 Id., pada 44-46
} 
pada pemahaman reflektif manusia sebagai makhluk ciptaan Tuhan Yang Maha Esa. Penghayatan Ketuhanan Yang Maha Esa dalam diri manusia ini berbeda pula dengan bangsa lain yang mengakui Tuhan. Penghayatan Ketuhanan Yang Maha Esa bermuara pada jiwa Pancasila sebagai weltanschauung bangsa, terutama dalam memandang kemanusiaan. Kemanusiaan yang dipahami merupakan kemanusiaan Indonesia yang menjunjung tinggi harkat dan martabat manusia. Setiap perilaku merupakan cerminan dari perikemanusiaan yaitu memanusiakan manusia. ${ }^{33}$ Pemahaman manusia Indonesia bertanggung jawab pada relasi multikompleks, yaitu diri dengan diri, diri dengan sesama manusia lainnya, diri dengan ciptaan lainnya, dan diri dengan Sang Pencipta. Hakikat dari kemanusiaan Indonesia ini oleh Notonagoro ${ }^{34}$ disebut sebagai makhluk monopluralis (satu pribadi manusia memiliki relasi yang bermacam-macam dan terpaut satu sama lain). Dengan demikian proposisi Sibural tidak terlepas dari Pancasila sebagai sumber nilai bangsa Indonesia sebagai ciri khas kriminologi nasional.

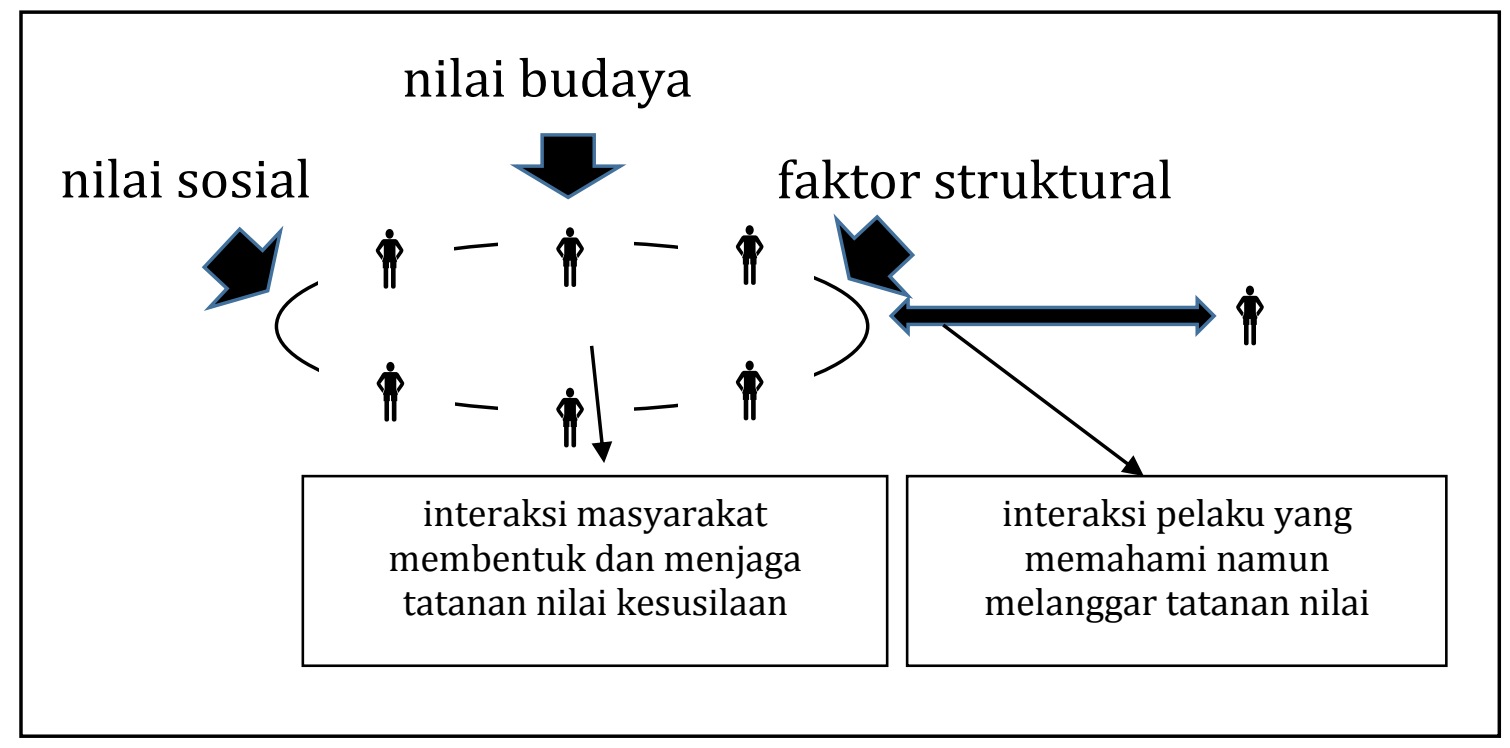

Bagan 2: Posisi Pelaku Kejahatan dalam Pendekatan Sobural

\footnotetext{
33 Bernard L. Tanya, Theodorus Yosep Parera \& Samuel F. Lena, Pancasila Bingkai Hukum Indonesia, Genta Publishing, Yogyakarta, 2015, hlm 54-55

34 Notonagoro, Pancasila secara Ilmiah Populer, Bina Aksara, Jakarta, 1983, hlm. 95-96
} 


\section{Studi Kasus Pornografi sebagai Balas Dendam berdasarkan Pendekatan}

\section{Sobural}

Pemahaman kontekstual dilakukan berdasarkan pendekatan Sobural yang dilandaskan pada nilai sosial, aspek budaya dan faktor struktural masyarakat tempat pelaku dan tempat dilakukannya perbuatan. Hal tersebut menurut Hidayat ${ }^{35}$ tidak terlepas dari realitas sosial dalam neotribalisme yang membangun komunitas baru berdasarkan keilmuwan, profesi dan jejaring sosial baru. Kondisi tersebut semakin mendukung model kultur serba tahu. Hasan ${ }^{36}$ menjelaskan bahwa teknologi informasi pada akhirnya membuka nilai-nilai global yang nirotentik masuk dalam kehidupan masyarakat nyata. Penting untuk diingat bahwa pornografi sebagai balas dendam mengandung 2 (dua) realitas masyarakat yang berbeda, yaitu masyarakat internet (netizen) dan masyarakat nyata tempat ia hidup. Kedua realitas tersebut juga turut dipertimbangkan dalam pendekatan Sobural sebagai upaya memahami pornografi sebagai balas dendam. Walaupun pelaku memiliki tatanan nilai dari masyarakat yang dia emban diri, tatanan nilai masyarakat internet memiliki perbedaan yang signifikan. Tatanan nilai yang diemban oleh masyarakat internet menurut Murray terbagi dalam 2 (dua) kelompok, Kelompok Cyberlibertarian yang menganggap kebebasan informasi sebagai ketentuan yang terutama dan mengesampingkan segala ketentuan hukum nasional yang membatasi serta Kelompok Cyberpaternalist yang menganggap pentingnya pengaturan kebebasan informasi dalam sebuah rezim lex informatica. Kelompok Cyberlibertarian menegaskan bahwa "Accordingly, the 'Law of Cyberspace' would largely be determined by a free market in regulation in which network users would be choose those sets they found most congenial."37 Sistim nilai sosial yang ditekankan lebih mengedepankan kebebasan dalam perkembangan penggunaan teknologi informasi. Tidak berarti kelompok cyberlibertarian

\footnotetext{
35 Komaruddin Hidayat, Neotribalisme, 22 September Koran Kompas, 2016, hlm 6.

${ }^{36}$ Kamarudin Hasan, Pancasila dan Arsitektur Negara Hukum Indonesia, 4 September-Februari 2013 Jurnal Digest Epistema, 2013, hlm 21-31. 37 Id.
} 
menolak adanya ketentuan hukum. Ketentuan hukum terbentuk berdasarkan kebebasan yang dibentuk secara alami oleh para pengguna internet sebagai hal yang diterima secara umum. Konteks pelembagaan nilai kebebasan tersebut terus dilakukan dalam setiap transaksi elektronik yang dilakukan oleh penyedia jasa internet atau provider internet. Lapisan kekuasaan dalam penggunaan internet pun tidak terbentuk sejak awal melainkan terbentuk saat itu juga dalam proses transaksi elektronik. Seseorang yang memiliki kemampuan mengoperasikan teknologi informasi lebih mahir dari pengguna lain akan mendapatkan 'posisi yang lebih kuat' dari segi akses perolehan dan pertukaran data. Jadi, cyberlibertarian dalam memetakan kekuasaan yang ada dalam masyarakat internet menempatkan penyedia jasa internet sebagai 'moderator lalu lintas informasi' sedangkan pengguna internet berada dalam gelanggang pertandingan informasi.

Kondisi masyarakat cyberpaternalist justru berkebalikan dengan masyarakat cyberlibertarian. Sistim nilai masyarakat cyberpaternalist sudah dibentuk sejak awal oleh penyedia jasa internet atau website yang tersedia di internet. Umumnya, penyedia jasa internet atau website mengadopsi konsep hukum nasional negara asal penyedia jasa internet atau pembuat website. Pemberlakuan hukum nasional tersebut biasanya ditandai dengan penggunaan alamat domain name akhir, berupa (.id untuk Indonesia, .au untuk Australia, .cn untuk Kanada). Sistem nilai masyarakat yang diberlakukan sama persis dengan konsep masyarakat negara asal tersebut. Hal yang menarik dalam proses pelembagaan nilai dilakukan kaum cyberpatenalist selain dengan menekankan aturan hukum yang berlaku dari negara yang bersangkutan tetapi mengkondisikan pengguna internet untuk mengikuti tahapan hukum yang diberlakukan. Pengguna internet yang ingin menggunakan fasilitas website mau tidak mau mempelajari syarat dan tahapan yang diberlakukan. Faktor struktural tampak jelas dipegang oleh penyedia jasa internet yang sejak awal menetapkan prosedur yang bersesuaian dengan hukum negaranya. 
Kondisi masyarakat internet tersebut jika dikaitkan dengan revenge porn ternyata lebih condong pada kondisi masyarakat cyberlibertarian. Walaupun Convention on Cybercrime telah dibuat tahun 2000 tidak berarti tiap negara memberlakukan ketentuan konvensi dengan ukuran dan model pengaturan yang sama, termasuk terkait pornografi. Pertukaran informasi masih tetap berlangsung tanpa batas waktu maupun wilayah bahkan satu ukuran yang sama. Apa yang dianggap melanggar kesusilaan di suatu negara mendapatkan penghayatan berbeda antar negara yang satu dengan lainnya. Batasan tampilan pornografi antara masyarakat Indonesia dan masyarakat Belanda tidak sama, mengingat latar belakang budaya dan penghayatan kemanusiaan yang berbeda. Akibatnya, informasi yang memuat pelanggaran kesusilaan tetap beredar dengan bebas sedangkan pembatasan diserahkan pada konteks masyarakat riil oleh tiap negara. Kondisi inilah yang menyebabkan pornografi melalui internet memiliki karakteristik berbeda dengan pornografi pada umumnya. Lim ${ }^{38}$ menjelaskan perbedaan tersebut dalam beberapa hal antara lain

(1) It can be infinitely copied and distributed at minimal cost.

(2) The quality of images does not degrade on copying.

(3) It is difficult for law enforcement to detec due to the size and structure of the Internet and the availability of encryption.

(4) It cannot be seized, in the normal sense of them, once it has been deemd illegal because it is very easy to-restock after a confiscation.

Pelaku revenge porn sebagaimana pengguna internet pada dasarnya memahami keempat hal ini beserta kondisi masyarakat internet. Kebebasan dan kemudahan mendapatkan dan mengunggah informasi dipahami sebagai hak privasi dari seseorang yang didukung oleh 'fatamorgana kebebasan informasi tanpa batas' yang ditawarkan oleh kelompok cyberlibertarian. Perbuatan mengunggah foto telanjang yang merupakan perbuatan merendahkan harkat dan martabat orang lain dipandang sebagai kebebasan diri untuk berbagi informasi dengan lainnya. Hal tersebut tampak dari digunakannya media sosial baik berupa facebook dan

38 Yee Fen Lim, Cyberspace Law: Commentaries and Materials, Oxford University Press, Victoria, 2007, hlm 395 
whatsapp yang merefleksikan kebebasan nilai diri yang tanpa batas, suatu kebiasaan yang dianggap sebagai hal yang baik secara subyektif, misalnya update status sebagai pemilik informasi yang 'bermanfaat' bagi dirinya sendiri. Pelaku pornografi sebagai balas dendam mengalami 'reinternalisasi nilai' kembali pada saat perbuatannya dinyatakan bersalah oleh lembaga penegak hukum masyarakat. Hal inilah yang menjadi arti penting dari putusan pengadilan demi membentuk keadilan substantif melalui mekanisme pemahaman "suara hati masyarakat"39. Kajian terhadap pemahaman kontekstual tersebut seharusnya memang diuraikan pada tiap kasus pornografi sebagai balas dendam pada pertimbangan putusan hakim.

1. Putusan Pengadilan Negeri Malang No. 645/Pid.Sus/2015/PN.Mlg, tanggal 17 Februari 2016 tentang penyebaran foto bugil mantan kekasih. ${ }^{40}$ Kasus berawal dari AS yang memiliki koleksi foto bugil korban yang merupakan kekasihnya berupa tampilan payudara, belahan payudara dan alat kelamin korban. AS merasa sakit hati karena mengalami putus cinta dengan korban. AS mengunggah foto korban dengan berbagai pose tersebut melalui media sosial Facebook dan Whatsaap. Pertimbangan hakim pada perbuatan AS hanya menekankan perbuatan AS telah memenuhi Pasal 29 UU Pornografi dengan tujuan agar foto bugil tersebut diketahui umum sehingga sifat melawan hukum perbuatan telah terpenuhi. Kajian Sobural terhadap perkara tersebut dipenuhi hakim dengan mempertimbangkan nilai kemasyarakatan yang mencela penyebarluasan pornografi. Masyarakat Malang sebagai bagian dari masyarakat Indonesia menilai tampilan payudara, belahan payudara dan alat kelamin perempuan merupakan bentuk perbuatan asusila. Aspek budaya juga nampak dari pertimbangan hakim saat melihat keinginan pelaku untuk menyebarluaskan sebagai bentuk merendahkan harga diri manusia yang tidak pantas. Sedangkan dari

\footnotetext{
${ }^{39}$ M. Syamsudin, Keadilan Prosedural dan Substantid dalam Putusan Sengketa Tanah Magersari: Kajian Putusan Nomor 74/PDT.G/2009/PN.YK 17 Jurnal Yudisial, 22 (2014)

40 Supra no 3
} 
faktor struktural, hakim mempertimbangkan perbuatan pelaku pornografi sebagai balas dendam sebagai upaya untuk mempermalukan korban patut dinilai tercela.

2. Putusan Pengadilan Negeri Mojokerto No. 425/Pid.Sus/2015/PN Mjk tanggal 24 November 2015 tentang Penyebarluasan Foto Telanjang oleh Mantan Pasangan Nikah Sirri. ${ }^{41}$

ES merupakan pasangan nikah siri dengan korban yang mendokumentasikan foto telanjang dirinya dan istrinya. Namun saat hubungan pernikahan tersebut harus berakhir, ES mengunggah foto-foto yang dimilikinya melalui akun Facebook miliknya. Pertimbangan hakim dalam putusan perkara tersebut menekankan pada telah dipenuhinya unsur menyebarluaskan pornografi dipahami dari perbuatan terdakwa mengunggah foto tersebut. Pertimbangan hakim tersebut menunjukkan pemahaman kontekstual dari perbuatan ES. Pemahaman nilai sosial dari perbuatan ES sebagai mantan pasangan nikah siri dianggap tidak pantas karena menyebarluaskan materi asusila yang dilarang masyarakat, secara khusus Mojokerto. Nilai budaya dari masyarakat Mojokerto sebagai upaya penghargaan kemanusiaan dilanggar pelaku dengan mengunggah foto asusila. Pemahaman dari faktor struktural dipahami hakim sebagai perbuatan yang tidak pantas dilakukan sebagai mantan suami yang seharusnya melindungi perempuan.

3. Putusan Pengadilan Negeri Probolinggo No. 78/Pid.B/2015/PN-Prob, tanggal 7 Juli $2015^{42}$ tentang Penyebarluasan Foto Bugil oleh Mantan Kekasih.

BS mengoleksi foto bugil kekasihnya dengan telpon genggam Sony Experia. BS merasa sakit hati karena telah diputus hubungan asmaranya dengan korban lalu menyebarluaskan foto bugil tersebut melalui media Multi Media

\footnotetext{
${ }^{41}$ Supra no 4

${ }^{42}$ Putusan Pengadilan, Putusan Pengadilan Negeri Probolinggo No. 78/Pid.B/2015/PN-Prob, https://putusan.mahkamahagung.go.id/main/pencarian/?q=78\%2FPid.B\%2F2015\%2FPN-Prob (terakhir diakses 12 Mei 2017)
} 
Message (MMS) kepada orang lain. Majelis hakim dalam perkara ini justru mempertimbangkan adanya pelanggaran norma kesusilaan masyarakat Probolinggo dengan menilai gambar telanjang yang disebarluaskan memunculkan eksploitasi seksual. Bentuk eksploitasi merupakan perbuatan merendahkan martabat kemanusiaan perempuan sebagai obyek seksual. Pertimbangan hakim tersebut menunjukkan pemahaman konstekstual dari sisi nilai sosial yang diemban oleh masyarakat Indonesia untuk tetap menjunjung tinggi kemanusiaan yang beradab. Pemahaman dari nilai budaya secara implisit dikemukakan oleh hakim dalam penilaian perbuatan pornografi sebagai balas dendam menciderai kemanusiaan masyarakat Probolinggo. Perbuatan BS dinilai dari faktor struktural dipahami hakim sebagai upaya menurunkan derajat kemanusiaan perempuan sebagai obyek seksual.

4. Putusan Pengadilan Negeri Ciamis No. 267/Pid.Sus/2015/PN.Cms tanggal 8 Desember $2015^{43}$ tentang Penyebarluasan Rekaman Adegan Persetubuhan oleh Mantan Suami.

NAR mengambil foto telanjang korban yang merupakan istrinya. NAR bercerai dengan istrinya sehingga menimbulkan sakit hati. NAR mengunggah foto tersebut melalui media sosial Facebook "JABLAT BUNTER" serta membuat cerita "ANAKKU PELAMPIASAN NAPSUKU" yang menceritakan hubungan seksual seorang ibu dengan anak kandungnya sendiri. Hal yang menarik dari pertimbangan hakim atas perkara ini yaitu

"Kesusilaan dimaknai sebagai perihal susila (baik budi bahasanya, beradab, sopan) adat istiadat yang baik, sopan santun, kesopanan, keadaban, pengetahuan tentang adab). Hakim menilai bahwa Terdakwa melakukan kegiatan interaksi dengan sistem elektronik yang berdiri sendiri atau dalam jaringan, mengenai gambar ataupun status yang ditulis dalam FB berupa satu atau sekumpulan data elektronik, termasuk tetapi tidak terbatas pada tulisan, gambar atau foto yang telah diolah yang memiliki arti atau

\footnotetext{
43 Putusan Pengadilan, Putusan Pengadilan Negeri Ciamis No. 267/Pid.Sus/2015/PN.Cms, https://putusan.mahkamahagung.go.id/main/pencarian/?q=267\%2FPid.Sus\%2F2015\%2FPN.C ms+ (terakhir diakses 12 Mei 2017)
} 
dapat dipahami oleh orang yang mampu memahaminya yang melanggar perihal susila (baik budi bahasanya, beradab, sopan), sopan santun, kesopanan, yaitu Terdakwa mengunggah foto telanjang korban dan beberapa foto lainnya serta membuat status atau cerita tentang "ANAKKU PELAMPIASAN NAPSUKU" di akun FB JABLAY BUNTER milik Tdw yang dapat dilihat oleh publik (umum)."

Hakim telah mempertimbangkan perkara ini secara kontekstual dengan menilai adanya kesusilaan yang dilanggar dari perbuatan pelaku dan pemahaman kontekstual kegiatan pengiriman foto melalui sistem elektronik telah melanggar kesusilaan (keberadaban). Nilai sosial dipahami hakim dalam hal pemahaman kesusilaan sebagai 'perihal susila' yang dimiliki masyarakat tidak sekedar peraturan hukum. Keberadaan nilai budaya mengemuka dalam hal pemahaman kesusilaan yang dilanggar NAR sebagai bentuk pelanggaran terhadap upaya membuat kehidupan manusia untuk lebih beradab. Upaya publikasi pornografi sebagai balas dendam membuktikan pelanggaran atas keberadaan manusia sebagai manusia yang memiliki keberadaban. Faktor struktural tampak pada saat hakim menilai perbuatan NAR sebagai upaya merendahkan kaum perempuan dengan membuat cerita fiktif dan merendahkan derajat kemanusiaan korban.

Berdasarkan keempat pertimbangan putusan hakim dalam kasus penyebarluasan pornografi, pornografi sebagai balas dendam dipertimbangkan sebagai kondisi khusus yang memberatkan perbuatan terdakwa. Pertimbangan kontekstual dalam hal pornografi sebagai balas dendam justru muncul dalam pertimbangan hakim bahwa perbuatan terdakwa membuat korban dan keluarganya merasa malu. Kondisi tersebut jelas bukan merupakan akibat yang dilarang dari penyebarluasan pornografi pada umumnya. Korban merasa malu merupakan hal yang dituju oleh pelaku pornografi sebagai balas dendam yang semula merasa aman pada saat informasi tidak disebarkan atau untuk konsumsi pribadi. Akibat yang dituju oleh pelaku pornografi sebagai balas dendam yaitu rasa malu atau kehormatan dari korban dan/atau keluarganya. Berbeda dengan pornografi pada umumnya, penyebarluasan materi pornografi menjadi tujuan 
utama dari pelaku. Jika dikaji lebih lanjut, kondisi pornografi sebagai balas dendam pada dasarnya merupakan bentuk khusus dari pornografi sebagaimana halnya pornografi yang melibatkan anak atau industri pornografi. Masing-masing pornografi memiliki kesamaan dalam hal penyebarluasan materi asusila atau pornografi namun berbeda dalam bentuk dan tujuan dilakukannya perbuatan. Pornografi yang melibatkan anak memiliki bentuk pornografi dengan muatan pelecehan atau eksploitasi seksual dengan obyek anak. Industri pornografi pun memiliki bentuk berbeda dalam hal produksi pornografi dan tujuan penyebarluasan materi asusila untuk tujuan keuntungan ekonomis.

\section{Penutup}

Penggunaan Pendekatan Sobural merupakan hal penting sebagai upaya memahami pornografi sebagai balas dendam secara kontekstual. Arti penting pendekatan Sobural terdapat pada pemahaman perbuatan pornografi sebagai balas dendam sebagai bagian dari tanggung jawab sosial yang harus diantisipasi oleh lingkungan masyarakat itu pula. Proses internalisasi nilai sosial yang berlaku di suatu masyarakat berbenturan dengan sistem nilai baru yang ditawarkan oleh cyberlibertarian yang menawarkan kebebasan tanpa batas dalam melakukan aktivitas informasi. Ketidakmampuan seseorang dalam memahami nilai yang terbaik menyebabkan pilihan yang salah sehingga ia berubah menjadi pelaku dalam pornografi sebagai balas dendam. Hasil penelitian pada 6 (enam) putusan hakim menunjukkan bahwa hakim telah menilai pornografi sebagai balas dendam berdasarkan pertimbangan kontekstual masyarakat dilakukannya perbuatan. Pertimbangan dari sisi sosial tampak dalam hal pemahaman hakim terhadap nilainilai moral yang berlaku di suatu masyarakat dikaitkan dengan perbuatan yang diperiksa. Nilai budaya dipertimbangkan pada saat hakim menilai hakikat kesusilaan sebagai nilai yang telah ada dalam diri manusia sebagai manusia bahkan menentukan kemanusiaan itu sendiri. Terakhir, faktor struktural diukur dari tujuan pelaku yang ingin merendahkan (membuat malu) korban melalui tersebarnya foto atau video asusila. 
Pornografi sebagai balas dendam berdasarkan pendekatan Sobural merupakan kejahatan seksual karena berkaitan dengan aktivitas seksual dan mengumbar hawa nafsu seksual dengan menyebarluaskan materi pornografi. Proses internalisasi nilai menjadi salah satu cara dalam menegakkan sistem nilai yang berlaku dalam diri pelaku sehinga ia mampu memahami hakikat dari larangan pornografi sebagai balas dendam. Hasil penelitian terhadap pertimbangan putusan hakim pada kasus pornografi sebagai balas dendam menunjukkan bahwa motivasi pornografi sebagai balas dendam dipertimbangkan hakim sebagai alasan memperberat pidana. Hakim lebih menilai perbuatan tersebut sebagai bagian dari pornografi dengan menekankan pencelaan terhadap pelanggaran norma kesusilaan yang diberlakukan dalam ketentuan hukum pidana. Sobural menyediakan 'jembatan solusi' bagi pemberlakuan norma kesusilaan yang dianut ketentuan hukum pidana. Pendekatan ini memiliki manfaat penting dalam menghidupkan kembali nilai sosial. aspek budaya dan faktor struktural masyarakat Indonesia.

\section{Daftar Pustaka}

\section{Buku:}

Freda Adler, Gerhard O.W. Mueller \& William S. Laufer, Criminology and the Criminal Justice System, Mcgraw Hill, New York, 2007.

Bernard L. Tanya, Theodora Yosep Parera, \& Samuel F. Lena, Pancasila sebagai Bingkai Hukum Indonesia, Genta Publishing, Yogyakarta, 2015.

E.Y. Kanter dan S.R. Sianturi, Asas-asas Hukum Pidana di Indonesia dan Penerapannya, Storia Grafika, Jakarta, 2012.

J.E. Sahetapy, Pisau Analisa Kriminologi: Pidato Pengukuhan Guru Besar Fakultas Hukum Universitas Airlangga, Fakultas Hukum Universitas Surabaya, Surabaya, 30 Juli 1983. 1992. Teori Kriminologi: Suatu Pengantar, Citra Aditya Bakti, Bandung,

Elfina Sahetapy, ed., Pisau Analisis Kriminologi, Citra Aditya Bakti, Bandung, 2005.

Yee Fen Lim, Cyberspace Law: Commentaries and Materials, Oxford University Press, Victoria, 2007. 
Moeljatno, KUHP: Kitab Undang-Undang Hukum Pidana, Bumi Aksara, Jakarta, 2011.

Notonagoro, Pancasila secara Ilmiah Populer, Bina Aksara, Jakarta, 1983.

R. Soesilo, Kitab Undang-Undang Hukum Pidana (KUHP) serta KomentarKomentarnya Lengkap Pasal Demi Pasal, Politeia, Bogor, 1974.

\section{Jurnal:}

A.M. Mujahidin, Hukum Progresif: Jalan Keluar dari Keterpurukan Hukum di Indonesia XXII 257 Varia Peradilan, 2007.

Christina Widowati, Hukum sebagai Norma Sosial memiliki Sifat Mewajbkan, 14 Jurnal Hukum ADIL, 2013.

Gabriella Febrianty, Philosophy, Pancasila and Modern Technology 292 Jurnal Yuridika, 2014.

Hwian Christianto, Penafsiran Hukum Progresif dalam Perkara Pidana 233 Jurnal Mimbar Hukum, 2011.

Indriyanto Seno Adji, Prospek Hukum Pidana Indonesia pada Masyarakat yang Mengalami Perubahan, Jurnal Keadilan, 2003.

Ismansyah \& Ermawati B, Permasalahan Delik Zina Yang Terdapat dalam Kitab Undang-Undang Hukum Pidana (KUHP) IX 1 Jurnal DELICTI, 2012.

Kamarudin Hasan, Pancasila dan Arsitektur Negara Hukum Indonesia, 4 September-Februari 2013 Jurnal Digest Epistema, 2013.

M. Syamsudin, Keadilan Prosedural dan Substantid dalam Putusan Sengketa Tanah Magersari: Kajian Putusan Nomor 74/PDT.G/2009/PN.YK Jurnal Yudisial, 2014.

Shigenori Matsuri, "The Criminalization of Revenge Porn in Japan", Washington International Law Journal Association, Vol. 24 No. 22015

Tyro Kirchengast, “The Limits of Criminal Law and Justice: 'revenge porn' Criminalisation, Hybrid Responses and The Ideal Victim", UniSA Student Law Review, Vol. 2

\section{Web Documents:}

Toetik Rahayuningsih, Kejahatan Kesusilaan dan Upaya Penanggulangannya: Studi pada Tingkat Penyidikan, Penuntutan dan Pemeriksaan di Pengadilan Negeri Surabaya, Fakultas Hukum Universitas Airlangga, 22 April 2014, http://adln.lib.unair.ac.id/go.php?id=gdlhub-gdl-res-2014-rahayuning34480\&q=kesusilaan, (terakhir diakses 12 Mei, 2017).

Danielle Keats Citron \& Mary Anne Franks, "Criminalizing Revenge Porn", https://law.yale.edu/system/files/area/center/isp/documents/danielle_citro

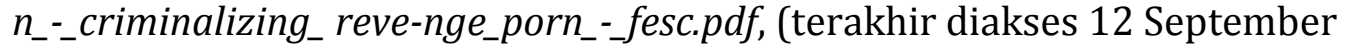
2017)

\section{Sumber Hukum Primer:}

Putusan Pengadilan, Putusan Pengadilan Negeri Malang No. 645/Pid.Sus/2015/PN.Mlg, tanggal 17 Februari 2016 
Putusan Pengadilan, Putusan Pengadilan Negeri Banyuwangi No.

726/Pid.Sus/2015/PN Bwi tanggal 3 Maret 2016

Putusan Pengadilan, Putusan Pengadilan Negeri Mojokerto No.

425/Pid.Sus/2015/PN Mjk tanggal 24 November 2015

Putusan Pengadilan, Putusan Pengadilan Negeri Probolinggo No.

78/Pid.B/2015/PN-Prob,

https://putusan.mahkamahagung.go.id/main/pencarian/?q=78\%2FPid.B

\%2F2015\%2FPN-Prob (terakhir diakses 12 Mei 2017)

Putusan Pengadilan, Putusan Pengadilan Negeri Ciamis No.

267/Pid.Sus/2015/PN.Cms,

https://putusan.mahkamahagung.go.id/main/pencarian/?q=267\%2FPid.S

us\%2F2015\%2FPN.Cms + (terakhir diakses 12 Mei 2017)

Putusan Pengadilan, Putusan Pengadilan Negeri Rokan Hilir No.

584/Pid.Sus/2014/PN.RHL,

https://putusan.mahkamahagung.go.id/main/pencarian/?q=584\%2FPid.S us\%2F2014\%2FPN.RHL+ (diakses terakhir 12 Mei 2017)

Lain-lain:

Komaruddin Hidayat, Neotribalisme, 22 September Koran Kompas, 2016. 